Journal of Southeast Asian

\title{
Book Review of Hein, J. (2006). Ethnic Origins: The Adaptation of Cambodian and Hmong Refugees in Four American Cities
}

Juchuan Colin Wang

University of Wisconsin College, colin.wang@uwc.edu

\section{Recommended Citation}

Wang, Juchuan Colin (2008) "Book Review of Hein, J. (2006). Ethnic Origins: The Adaptation of Cambodian and Hmong Refugees in Four American Cities," Journal of Southeast Asian American Education and Advancement: Vol. 3 : Iss. 1, Article 21.

DOI: $10.7771 / 2153-8999.1117$

Available at: https://docs.lib.purdue.edu/jsaaea/vol3/iss1/21

This document has been made available through Purdue e-Pubs, a service of the Purdue University Libraries. Please contact epubs@purdue.edu for additional information.

This is an Open Access journal. This means that it uses a funding model that does not charge readers or their institutions for access. Readers may freely read, download, copy, distribute, print, search, or link to the full texts of articles. This journal is covered under the CC BY-NC-ND license. 


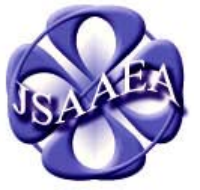

Volume 3

\section{Journal of Southeast Asian America $\begin{gathered}\text { A peer-reviewed } \\ \text { pholarly jounal } \\ \text { published by the }\end{gathered}$ National Association Education \& Advancement for the Education \& Advancement of Cambodian, Laotian, and Vietnamese Www.JSAAEA.org}

\section{Book Review}

Hein, J. (2006). Ethnic Origins: The Adaptation of Cambodian and Hmong Refugees in Four American Cities. New York: Russell Sage Foundation. 336 pp. \$37.50 (Hardback). ISBN10: 0871543362 http://www.russellsage.org/publications/books/060110.192473/

\section{Reviewed by Juchuan Colin Wang University of Wisconsin College}

While a growing number of immigration scholars are adopting transnational perspectives for understanding immigrant adaptations in host societies, most still focus mainly on their economic adaptation and most still ignore the cultural makeup of the immigrants' sending country. In Ethnic Origins, Jeremy Hein strives to demonstrate that an immigrant group's homeland values and norms can strongly influence their unique cultural and political adaptation to the new society. For this, and its multi-method, comparative study design, thorough research, and lucid writing, the book was a volume for the prestigious Rose Series in Sociology in 2006.

Hein defines "ethnic origin" as an immigrant group's homeland experiences in terms of their religious belief, their kinship structure, their status in the social stratification system, and their involvement in intraethnic and interethnic conflicts. This ethnic origin, Hein argues, informs an immigrant group's conception of societal membership or what it means to belong to a people. Depending on their historical experiences, a group's ethnic origin can be characterized as having "porous ethnic boundary" and "liminal ethnic identity" versus "hermetic ethnic boundary" and "polarized ethnic identity." In social psychological terms, the former beckons racial ethnic

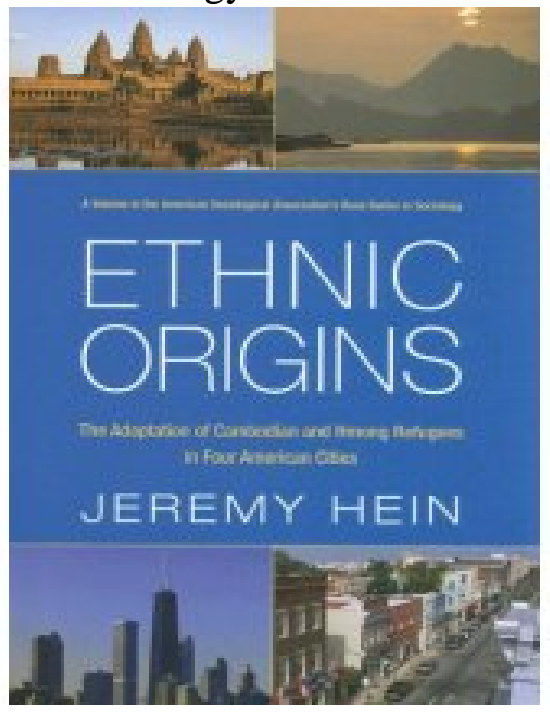
disappearance, the latter stands for racial ethnic affirmation and resistance. Hein explores how these varying qualities in ethnic origin influence an immigrant group's cultural and political adaptation to their host society. More specifically, he addresses how these varying qualities affect an immigrant group's identification with pan-ethnic categories (such as Asian American)

\section{@)}

SOMERIGHISRESERVEDReaders are free to copy, display, and distribute this article, as long as the work is attributed to the author(s) and the Journal of Southeast Asian American Education \& Advancement, it is distributed for noncommercial purposes only, and no alteration or transformation is made in the work. More details of this Creative Commons license are available at http://creativecommons.org/licenses/by-nc-nd/3.0/. All other uses must be approved by the author(s) or JSAAEA. 
and American citizenship and how these varying qualities affect an immigrant group's perceptions and reactions to societal racism and racial inequalities.

To demonstrate that immigrants' ethnic origins matter for their adaptation to the new society, Hein uses archival sources, standardized surveys, personal interviews, and peer group conversations to compare first generation Cambodian and Hmong responses across four cities. Two sites are considered "small towns." They are Eau Claire, Wisconsin and Rochester, Minnesota. Two sites are considered large "urban cities.” They are Milwaukee, Wisconsin and Chicago, Illinois. The choice of Cambodian and Hmong refugees are strategic. The two groups seem to share similar political and economic status in the United States, they are from the same sending region (Southeast Asia) and yet seem to differ markedly in terms of their cultural and political experiences in their countries of origin. To analyze the cultural impact of ethnic origin (religion and kinship), most social and demographic backgrounds of the respondents are held constant. Therefore, whatever differences we observe between the two groups with regard to their identity formation and their reactions to the American racial hierarchy must be interpreted as "ethnic origin" effects, especially if the between group differences remain regardless of small town versus urban city contexts.

Following this design, Hein reveals that regardless of their urban locale, compared with Cambodians, the Hmong feel less affiliated with the Asian American pan-ethnic identity; they are more likely to use "we" when discussing why a stereotype is offensive and describe how other Hmong are affected by it. They are more likely to perceive greater institutional discrimination irrespective of personal experiences with such discriminations. Consequently, they are more politically mobilized, as evidenced in their organized protests against the welfare reform acts of 1996.

A major strength of Hein's study is that he does not demonstrate "ethnic origin" effect simply as a default explanation after controlling for alternative accounts. Rather, he spends two chapters detailing the ethnic history of Hmong and Cambodians, delineating their different characteristics at their homeland, and he then analyzes his immigrant respondents' narratives very carefully to determine if they demonstrate patterns consistent with those characteristics. The result is that these dense, substantive discussions provide an empirically based interpretation on how ethnic origins were related to observed differences in ethnic group adaptations. He tries to show, for example, how Hmong's animist religion, ancestral worship, patriarchical clan system, perpetual minority status, and experiences with helping Americans in the Vietnam war and then feeling abandoned, give rise to an identity schemata (a word Hein did not use) that is characterized by "hermetic boundary" and "polarized identity." This in turn shapes the ways they make sense of American identity and American racial inequality. In contrast, he contends that Cambodians' Theravada Buddhism emphasizes individual ethical conduct versus conformity. Khmer kinship is bilateral and fictive kin can be as important as blood kin. Moreover, Cambodians experienced intraethnic rather than interethnic violence prior to their arrival at the United States. Together, these beliefs, customs and experiences minimize the salience of ethnic boundaries. They allow Cambodians to be more open to Asian pan-ethnicity (p. 143), and foster a more individualistic perception of American prejudices (p. 195). 
I have to admit, though, that I read the book with a great deal of trepidation. Does the ethnic origin hypothesis run the risk of reifying "culture” in immigrant identity studies? After all, as Hein is keenly aware of, he is using a very traditional concept of "culture," as "values and norms socialized at one's home country." It is a concept that has now largely been replaced by culture as a "tool-kit" conceptualization in both sociology and anthropology. The culture-as-atool-kit notion sees "culture" as "repertoires" from which people construct strategies of action (Swidler 1986). It assumes that culture is fragmented, lacking coherence, and is inconsistent in its demonstrations (DiMaggio 1997).

Hein insists that he does not reify culture and that his concept of "culture” is historically and structurally situated. He contends that culture, in the form of religion and kinship structure, is only one of three components that constitute his holistic concept of "ethnic origin," the others being a group's political and economic status and its history of ethnic conflict with other groups in a society. In other words, culture is not considered an individual causal variable. It affects host society adaptation only through contributing to the formation of the unique qualities of a group’s ethnic origin (p. 32).

Fair enough. But the difference between the culture as "values and norms" and the culture as "tool-kit" concepts lies not only in whether culture is embedded in history and social structure or not. It lies also in the fact that the latter questions the very existence of a unified symbolic system internalized among the immigrants of an ethnic group. As a result, the latter focuses on how immigrants use "cultural repertories" rather than how "values and norms" direct immigrants’ responses.

Guided by this culture-as-tool-kit notion and culture-in-action approach, I am suspicious of Hein's depiction that assumes one Hmong/Cambodian homeland experience or culture among the first generation refugees that produced one Hmong/Cambodian identity schemata. I am also weary of the focus on snapshot narratives in surveys and focus groups to the exclusion of how these narratives are used in immigrants' encounters with the outside world ${ }^{1}$.

To Hein's credit, he diligently recorded some diversity of voices within the Hmong and Cambodian communities and he particularly pointed out the interaction effect of ethnic origin and small town size in augmenting perceptions of institutional discrimination among both the Hmong and the Cambodians. Nevertheless, the diverse voices only came up as cautionary remarks rather than fundamental theoretical challenges to the assumptions of the ethnic origin hypothesis (p. 143). And the interaction effect only serves to demonstrate that contexts may cue in or cue out the schemata. There is no possibility for Hmong to have several schemata to choose from and there is no possibility for Hmong to invent a new Hmong identity, in the ethnic origin theoretical framework. As a result, we also have no way to determine whether Hein's interviewees' narratives actually reflect strategic self-presentations or constraints of cognitive frameworks.

\footnotetext{
${ }^{1}$ Hein did have earlier studies $(1998,2001)$ that focused on both the diversity and the use of culture among Hmong in his other research projects. But the insights from those studies are not theoretically woven into the "ethnic origin" theme of this book.
} 
In addition to that theoretical reservation, I also question the choice of Rochester, Minnesota and Eau Claire, Wisconsin for determining how ethnic culture can influence adaptation independent of small town settings. Hein attempts to demonstrate that although both are characterized by "small-town hospitality and hate," the Cambodians in Rochester and the Hmong in Eau Claire react to pan-ethnic categories and societal racism differently. But according to the 2000 Census, the two small towns are markedly different in terms of their ethnic make-ups. Rochester boasts 10 percent foreign-born population while Eau Claire only 3 percent. Moreover, while Cambodians constitute 10 percent of the Asian population in Rochester, the Hmong are 60 percent of the Asian population in Eau Claire. With such different ethnic contexts, I would suspect that the ethnic population context could have played a larger role than the differences in Hmong versus Cambodian "ethnic origins.”

In summary, Ethnic Origin is a very dense, well-written, well-designed, carefully researched, and theoretically provocative book. It contains a very expansive literature review as the author evaluates the ethnic origin hypothesis against other immigration literature. It also contains detailed methodological notes in the Appendices that should be valuable for students interested in immigration and comparative research. It deserves page-to-page reading. Ultimately, my reservations about the book's central argument are theoretical. It is the author that demonstrated his argument empirically.

\section{References}

Beger, R. R. \& Hein, J. (2001). Immigrants, culture, and American courts: A typology of legal strategies and issues in cases involving Vietnamese and Hmong litigants. Criminal Justice Review, 26, 38-61.

DiMaggio, P. (1997). Culture and cognition. Annual Review of Sociology, 2, 263-287.

Hein, J. (1998). The Hmong cultural repertoire: Explaining cultural variation within an ethnic group. Hmong Studies Journal, 2, 1-15.

Swidler, A. (1986). Culture in action: Symbols and strategies. American Sociological Review, 51, 273-286.

\section{About the Reviewer}

Juchuan Colin Wang is an assistant professor of sociology at the University of Wisconsin Marathon County campus. He received his Ph.D. degree in sociology at Texas A\&M University. His research interests are in the Sociology of Culture and the Sociology of Race and Ethnic Relations. He is currently doing research on how Southeast Asian Americans and European Americans react to domestic violence scenarios. He is also exploring ways to study "cultural capital” in contemporary China. 


\title{
Editor
}

Dr. Wayne E. Wright

University of Texas, San Antonio

Associate Editors

Dr. Chhany Sak-Humphry

University of Hawaii

Dr. KimOanh Nguyen-Lam

California State University, Long Beach

Book Review Editor

Dr. Leslie Turpin

School for International Training

\section{Creative Works Editor}

Phouang Hamilton

Washington Office of Superintendent of Public Instruction

\section{Special Advisor}

Anne Frank

University of California, Irvine, Southeast Asian Archives

\author{
Editorial Assistant \\ Mariana Kuhl \\ University of Texas, San Antonio
}

Comments and questions for the editorial staff may be directed to jsaaea@lists.sis.utsa.edu

\section{Editorial Review Board}

\author{
Dr. Carl L. Bankston III \\ Tulane University \\ Dr. Phala Chea \\ Lowell Public Schools \\ Dr. Changming Duan \\ University of Missouri, Kansas City \\ Dr. Nancy H. Hornberger \\ University of Pennsylvania \\ Dr. Peter Nien-Chu Kiang \\ University of Massachusetts, Boston \\ Dr. Stacey Lee \\ University of Wisconsin, Madison \\ Dr. Sue Needham \\ California State University, Dominguez Hills
}

Dr. Pollie Bith-Melander

University of Hawaii at Manoa

Dr. George Chigas

University of Massachusetts, Lowell

Dr. Sophal Ear

Syracuse University

Dr. Samlong Inthaly

Minneapolis Public Schools

Dr. Kevin K. Kumashiro

University of Illinois, Chicago

Dr. David Chanpannha Ley Montgomery County Public Schools

Dr. Bic Ngo

University of Wisconsin-Madison 


\author{
Dr. Max Niedzwiecki \\ Rights Working Group \\ Dr. Clara Park \\ California State University, Northridge \\ Dr. Loan T. Phan \\ University of New Hampshire \\ Dr. Karen Quintiliani \\ California State University, Long Beach \\ Dr. Fay Shin \\ California State University, Long Beach \\ Dr. Yer J. Thao \\ Portland State University \\ Dr. Khatharya Um \\ University of California, Berkeley \\ Dr. Terrence G. Wiley \\ Arizona State University
}

\author{
Dr. Leakhena Nou \\ California State University, Long Beach \\ Dr. Mark Pfeifer \\ Texas A\&M University, Corpus Christi \\ Dr. Bounlieng Phommasouvanh \\ Minnesota Department of Education \\ Dr. Kalyani Rai \\ University of Wisconsin, Milwaukee \\ Dr. Nancy J. Smith-Hefner \\ Boston University \\ Dr. Myluong Tran \\ San Diego State University \\ Dr. Linda Trinh Vo \\ University of California, Irvine \\ Dr. Zha Blong Xiong \\ University of Minnesota
}

Dr. Kou Yang

California State University, Stanislaus

\section{Doctoral Student Editorial Review Board}

\section{Keo Chea}

University of Pennsylvania

Loan Dao

University of California, Berkeley

Ha Lam

Arizona State University

Vanna Som

Harvard University

Giang Pham

University of Minnesota

Tinou Tran

University of Houston, Texas

Phitsamay Sychitkokhong Uy

Harvard University
Vichet Chhuon

University of California, Santa Barbara

Annie BichLoan Duong

San Joaquin County Office of Education

Ravy Lao

University of California, Santa Barbara

Rassamichanh Souryasack

University of California, Santa Barbara

Layheng Ting

State University of New York, Albany

Loan Tran

University of California, Santa Barbara

Yang Sao Xiong

University of California, Los Angeles 